\title{
Deprivation of Retirement Benefits on Divorce through Living Annuities in South Africa
}

\author{
Motseotsile Clement Marumoagae* \\ University of the Witwatersrand, Johannesburg, South Africa \\ Clement.Marumoagae@wits.ac.za
}

\begin{abstract}
This article discusses the law regulating living annuities when spouses in South Africa are divorcing. It demonstrates that South African courts have interpreted the law to prejudice non-member spouses financially. It argues that courts have failed to consider matrimonial principles when determining whether living annuities are susceptible to being shared on divorce. It argues further that adequate consideration of matrimonial principles will render it impossible for retirement fund members to prejudice their spouses financially by purchasing living annuities without the consent of such spouses, particularly when married in community of property. Disregarding matrimonial law principles may lead to deprivation of property.
\end{abstract}

\section{Keywords}

Living annuities, pension interest, divorce, community of property, accrual

\section{INTRODUCTION}

The law regulating the sharing of pension interests in South Africa is not settled and there are outstanding issues that still need to be clarified. ${ }^{1}$ A number of issues have proved to be a source of concern arising out of the division of the retirement fund members' pension interests due to divorce, one of which relates to retirement fund members (hereafter "member spouses") purchasing living annuities with their accrued pension interests. This article discusses the potential prejudice that such transactions have, or may have, on persons who are married to these member spouses (hereafter "non-member spouses") when retirement benefits became due before divorce and living annuities are purchased immediately thereafter. The law as it is currently applied is that living annuities are not assets that fall within joint estates

Associate professor, School of Law, University of the Witwatersrand. LLB LLM (University of the Witwatersrand), LLM (North West University), PhD (University of Cape Town).

1 See C Marumoagae "The law regarding pension interest in South Africa has been settled! Or has it? With reference to Ndaba v Ndaba (600/2015) [2016] ZASCA 162" (2017) 20

Potchefstroom Electronic Law Journal 1. 
and cannot therefore be shared when spouses divorce. ${ }^{2}$ Unfortunately, some of the practical prejudicial challenges that arise from the purchase of living annuities with retirement benefits when parties are divorcing have not received adequate judicial and academic attention. In this article, I demonstrate that our courts have incorrectly and strictly applied pension law (and to some extent insurance law) principles when dealing with living annuities and divorce without adequate regard to matrimonial principles, to the prejudice of financially weaker spouses, most of whom, in practice, are women.

First, I start by providing a brief overview of the South African law regarding pension interests. Secondly, I assess the legal nature of living annuities and circumstances under which accrued retirement benefits can be used to purchase these insurance products in South Africa. It will be shown herein that in certain financial transactions, a spouse married in community of property cannot make investment decisions without the consent of the other spouse. Further that the purchase of living annuities from accrued retirement benefits falls within such transactions. Thirdly, I will argue that the extent to which the law permits member spouses to purchase living annuities through accrued retirement benefits without the consent of their non-member spouses amounts to arbitrarily depriving such non-member spouses of their property. Throughout the article, I will argue that the current application of the law effectively makes living annuities financial products that enable member spouses on divorce to legally prevent their spouses from receiving accrued retirement benefits to which they are entitled. I will recommend law reform that should require adequate engagement with matrimonial principles when dealing with disputes relating to the purchasing of living annuities when parties are divorcing. While the terms "pension interest", "pension benefits", "retirement benefits" and "retirement savings" may be defined differently and may possibly mean different things, it will be assumed in this article that they mean the same thing and will be used interchangeably, depending on context and line of argument. ${ }^{3}$

\section{CURRENT LAW REGARDING PENSION INTEREST}

Section 7(7) of the Divorce Act $^{4}$ deems members' retirement benefits that accrue to them because of divorce to be assets in their personal estates. ${ }^{5}$

2 See generally, M $v$ M (14/26868) [2016] ZAGPJHC 387 (10 August 2016) and ST v CT 2018 (5) SA 479 (SCA).

3 For a critical discussion of how these phrases have been confusingly and "incorrectly" defined and used by the courts and academics in South Africa, see C Marumoagae "An argument for necessary amendments to the legislative provisions regulating the sharing of retirement savings upon divorce in South Africa" (2018) 30/2 South African Mercantile Law Journal 280.

4 Divorce Act 70 of 1979.

5 See Old Mutual Life Assurance Co (SA) Ltd \& another v Swemmer 2004 (5) SA 373 (SCA), para 18, where it was held that “... s 7(7)(a) of the Divorce Act 'deems' a member spouse's 'pension 
When members are married in community of property, once such assets are regarded as their assets, they would constitute patrimonial assets that should fall into their joint estates. This entails that the amount of money invested by retirement funds on behalf of their divorcing members should be considered when determining the value of the divorcing spouses' joint estates. When members are married out of community of property with the application of the accrual system and the non-member spouse's estate at the dissolution of the marriage is smaller than that of the member spouse, the pension interest will be considered when the accrual is calculated. Pension interest is a financial asset that forms part of the member spouse's assets whose estate is larger than that of their spouse. Section 3 of the Matrimonial Property Act $^{6}$ (hereafter MPA) provides that the spouse with a smaller estate acquires a claim against the spouse with the larger estate or his or her estate “... for an amount equal to half of the difference between the accrual of the respective estates of the spouses". ${ }^{7}$

The law makes provision for spouses to have a clean break when divorcing by making it possible for non-member spouses to be able to immediately claim their portion of their member spouses' pension interests upon divorce. ${ }^{8}$ Thus, divorce is one of the legislatively recognized events that lead to the accrual of members' retirement benefits for the benefit of non-member spouses if the parties are married in accordance with the marital regime that enables sharing of patrimonial benefits of the marriage. The date of accrual of retirement benefits has led to unnecessary confusion in regard to the way these benefits should be described. In Eskom Pension and Provident Fund $v$ Krugel and Another, ${ }^{9}$ Maya JA (as she then was) held that a pension interest:

“... is an award to the non-member spouse of any part of this interest (and no other amount held by the fund in respect of the member spouse) calculated as

contd

interest' to be an asset in his or her estate for purposes of the determination of the patrimonial benefits to which the parties to a divorce action may be entitled. ... 'A pension interest is not a real asset that is open to division'."

6 Matrimonial Property Act 88 of 1984.

$7 \quad M v M(4906 / 2016)$ [2018] ZAFSHC 161 (30 July 2018), para 55. Sec 4(1)(a) of the Matrimonial Property Act provides that " $[t]$ he accrual of the estate of a spouse is the amount by which the net value of his estate at the dissolution of his marriage exceeds the net value of his estate at the commencement of that marriage."

8 See generally, Wiese $v$ Government Employees Pension Fund and Others [2011] 4 All SA 280 (WCC), Wiese v Government Employees Pension Fund and Others 2012 (6) BCLR 599 (CC) and Ngewu and Another v Post Office Retirement Fund and Others 2013 (4) BCLR 421 (CC). See also S Mothupi "Some practical effects of the Financial Services Laws General Amendment Act 2008 on amending section 37D(4) of the Pension Funds Act" (2010) 22 South African Mercantile Law Journal 214 at 220 and C Marumoagae "Breaking up is hard to do, or is it? - The clean-break principle explained" 2013 (Oct) De Rebus 38. 
at the date of the divorce but with effect from a certain date in the future when the pension benefit accrues to the member spouse. Once the pension benefit has accrued i.e beyond the date of divorce at which time the pension interest converts into a pension benefit...".

It is very difficult to understand how a financial award that will be calculated when the parties are divorcing but with reference to the date the "pension benefit accrues" will be converted into a pension benefit. In other words, a pension benefit that has not yet accrued is a pension interest, and after it has accrued it is a pension benefit. With respect, this is not only linguistically incorrect, it is also unnecessarily confusing. One academic has also attempted, albeit unsuccessfully, to rescue Maya JA's confusing distinction of pension benefit from pension interest. ${ }^{10}$ According to Heaton "[a] pension interest is an interest that has not yet accrued to the member by the time of divorce [and] ... [a] pension benefit is a benefit [withdrawal benefit] that has already accrued to the member". ${ }^{11}$ It is submitted that, given the fact that the law enables a clean break between the parties, this is an artificial distinction that does not have any practical relevance. The amount held by retirement funds amounts to benefits that would be due to members when any of the identified contingent events in the rules occur. The law has established divorce as a contingent event that would enable non-member spouses to be able to claim portions of such benefits immediately after courts have pronounced their divorce. In other words, the benefits held by retirement funds accrue to member spouses immediately when courts dissolve their marriages. It is important to note that the phrase "accrual of pension benefits", in the context of money invested and saved on behalf of retirement fund members, simply entails money becoming due to member spouses and not necessarily being paid to such members. Thus, when such benefits accrue to members, such members become entitled to claim what is due to them in accordance with the rules of their retirement funds. It has been argued that "[i]n order to avoid any unnecessary confusion of what such money should be termed at what particular time ... it should simply be referred to as 'retirement savings'."12

There are several pension law-related statutes that prohibit the deduction of retirement savings subject to statutory allowable deductions. ${ }^{13}$ Section $37 \mathrm{D}(4)$ (a)(i)(aa) of the Pension Funds Act (PFA) is one of the clear provisions that allow for the court to order the deduction of retirement benefits. It provides that:

10 J Heaton "Proprietary consequences pension fund" in Heaton (ed) The Law of Divorce and Dissolution of Life Partnerships in South Africa (2014).

11 Id at 79.

12 Marumoagae "An argument for necessary amendments", above at note 3 at 287.

13 See sec 21 of the Government Employees Pension Law (Proclamation 21 of 1996), sec 7 of the Transnet Pension Fund Act 62 of 1990, sec 10B(1) of the Post and Telecommunication-Related Matters Act 44 of 1958, sec 2 of the General Pensions Act 29 of 1979 and sec 37A of the Pension Funds Act 24 of 1956 (PFA). 
"[f]or purposes of section 7(8)(a) of the Divorce Act, 1979 (Act No. 70 of 1979), the portion of the pension interest assigned to the non-member spouse in terms of a decree of divorce or decree for the dissolution of a customary marriage is deemed to accrue to the member on the date on which the decree of divorce or decree for the dissolution of a customary marriage is granted, and, on the written submission of the court order by the non-member spouse must be deducted by the pension fund or pension funds named in or identifiable from the decree." 14

It is unfortunate that certain retirement funds have been reading and implementing this provision restrictively, leading to their refusal to pay nonmember spouses shares based on what they regard as divorce orders that do not comply with section $7(8)$ of the Divorce Act. ${ }^{15}$ In Barnard $v$ Municipal Gratuity Fund, the Pension Funds Adjudicator correctly observed that “... many complaints before this tribunal indicate that pension funds are frequently incorrectly cited, or not mentioned by name at all, even though they can be identified from the context". ${ }^{16}$ Most retirement funds appear not to be implementing section $37 \mathrm{D}(4)(\mathrm{a})(\mathrm{i})(\mathrm{aa})$ of the PFA properly. They appear to be focusing on the requirement that retirement funds must be named in the divorce decrees. They seem to ignore the requirement that divorce orders must, at the very least, be identifiable. This is one of the legal uncertainties that non-member spouses are confronted with when attempting to access their portions of their member spouses' pension interests. ${ }^{17}$

It was correctly determined in Dosson $v$ Cape Municipal Pension Fund that "[t]he ordinary and literal meaning of the word 'identifiable' means something that can be proved or is recognisable."18 It has been argued that the

14 PFA, sec 37D(4)(a)(i)(aa). See also Mosala $v$ Superfund Pension Fund and another [2019] 1 BPLR 198 (PFA), para 5.3, where the Adjudicator held that "[s]ection 7(7) and (8) of the Divorce Act creates an exception to the general statutory prohibition set out in section 37A(1) of the Act. Therefore, a divorce court is allowed to order the payment or transfer of a portion of a member spouse's notional benefit to the non-member spouse as at the date of the divorce order. It is clear that in terms of the amended section $37 \mathrm{D}(1)(\mathrm{e})$ of the Act the divorce benefit accrues to the non-member spouse on the date of divorce."

15 See C Marumoagae "Prejudice emanating from non payment of pension interests due to what is contained in or omitted from divorce decrees" (2018) 51/1 De Jure 101 at 111.

16 [2009] 2 BPLR 143 (PFA), para 41. She further held that “... many of the complaints before this tribunal involve people who are not legally qualified to understand the requirement that a Fund should be named clearly in the decree of divorce. It also happens that people who are legally qualified sometimes fail to understand and comply with the requirement relating to the naming of a fund in a divorce order. Thus, it is unduly onerous to require a party whose claim has fallen due to make a formal application for rectification of the divorce order even in circumstances where the fund is identifiable from the facts or circumstances" (para 41).

17 M Mamashela "A review of the problems encountered by a non-member spouse in accessing their half share of the pension interest during divorce in South Africa" (2018) 51/1 De Jure 17 at 18.

18 [2009] 1 BPLR 12 (PFA), para 5.13. 
naming of the retirement fund member in the divorce decree can be one of the methods used to identify the retirement fund to which he or she is a member. ${ }^{19}$ While not necessarily common, it is, nonetheless, possible at the date of divorce for a member spouse to be contributing to more than one retirement fund. In addition to a retirement fund to which their employer is a contributing employer, a member spouse may also be contributing to a non-occupational retirement fund, such as a retirement annuity fund established by a financial institution. ${ }^{20}$ Under these circumstances, the court must be asked to make an order against all the retirement funds to which the member spouse is contributing. Nonetheless, in practice, a non-member spouse can ask for further particulars in order to obtain the correct names of all the retirement funds to which the non-member spouse is contributing, ${ }^{21}$ or even bring an interlocutory application to compel the member spouse to provide such information. ${ }^{22}$

Section 7(8) of the Divorce Act provides courts with discretion when granting divorce decrees to order retirement funds to pay non-member spouses' parts of retirement savings that accrued to member spouses because of divorce. Initially, there was some confusion regarding the status of the portion of the pension interests that courts can order retirement funds to pay to nonmember spouses. ${ }^{23}$ In 2016, the Supreme Court of Appeal (hereafter "SCA") in Ndaba $v$ Ndaba clarified the law in this regard, and held that "[t]he language of s7(7)(a) is clear and unequivocal. It vests in the joint estate the pension interest of the member spouse for the purposes of determining the patrimonial benefits, to which the parties are entitled as at the date of their divorce." 24 This essentially means that non-member spouses who are married in community of property are entitled to their member spouses' pension interests upon divorce. ${ }^{25}$ Non-member spouses who are married out of community of property with the application of the accrual system will only be entitled to the portions of their member spouses' pension interests if they demonstrate that at the time of the divorce the value of their estates is less than that of their member spouses. $^{26}$

19 C Marumoagae "Should retirement funds be named or identified in divorce orders?" (2019) (Oct) De Rebus 10.

20 See N Jeram "Is it still necessary to obtain a court order against a fund? A rebuttal" (2017) (June) De Rebus 28.

21 Rule 16 of the Magistrate Court Rules.

22 Rule 21 of the Uniform Rules of Court.

23 See conflicting judgments of Sempapelele $v$ Sempapelele $\&$ another 2001 (2) SA 306 (O) and Maharaj $v$ Maharaj \& others 2002 (2) SA 648 (D). See also Motsetse $v$ Motsetse [2015] 2 All SA 475 (FB), Elesang $v$ PPC Lime Ltd \& others 2007 (6) SA 328 (NC) and Kotze $v$ Kotze $\&$ another [2013] JOL 30037 (WCC).

242017 (1) SA 342 (SCA).

25 Ndaba $v$ Ndaba 2017 (1) SA 342 (SCA), para 26. See Marumoagae "The law regarding pension interest in South Africa has been settled!", above at note 1 at 8 .

Matrimonial Property Act, secs 3 and 4. 
When married member spouses' retirement savings accrue to them before their divorce, there is no legal provision that prevents them from accessing such benefits or even dealing with them as they please. Member spouses can cash in such benefits in accordance with the rules of their funds. By the time the court dissolves their marriage there will be no "pension interests" that could be considered by the court for the benefit of non-member spouses. Once accrued, this benefit constitutes the patrimonial benefit of the marriage, particularly when parties are married in community of property. However, in practice the proceeds of this benefit will be paid into the bank account of the member spouse. The member will determine how it will be used. This benefit is seldom apportioned between the spouses. It is even worse when parties are engaged in divorce proceedings. During this time, the member spouse can "legally" hide, dissipate or waste his or her financial assets, including money received from the retirement fund. There is evidence in South Africa of financially stronger spouses, who are usually men, "wasting or secreting assets with the intention (particular state of mind) of defeating [their financially weaker spouses, usually women's] claim[s] in the divorce proceedings". ${ }^{27}$

\section{LIVING ANNUITIES}

\section{The legislative framework}

In terms of section 1 of the Income Tax Act, ${ }^{28}$ a living annuity "means a right of a member or former member of a pension fund, pension preservation fund, provident fund, provident preservation fund or retirement annuity fund, or his or her dependant or nominee, or any subsequent nominee, to an annuity purchased from a person or provided by that fund on or after the retirement date of that member or former member ...". This provision defines a living annuity in terms of a right that a member, former member, or member's beneficiary has on an annuity that has been purchased from an external source or provided by the fund from the date the member exited the fund. The Income Tax Act does not provide a definition of the word annuity. This word is defined in section 1 of the Government Employees Pension Law, ${ }^{29}$ as "an amount which is paid annually". According to the Association for Savings \& Investment South Africa, a living annuity “... is a special type of compulsory purchase annuity offered by insurers and retirement funds, under which the income (or annuity amount) is not guaranteed but is dependent on the performance of the underlying investments". ${ }^{30}$ A living annuity can be understood to be a financial product that retirement fund members on the

27 Carmel Trading Co Ltd v Commissioner, South African Revenue Service and others 2008 (2) 433 (SCA) 435C-D.

28 Income Tax Act 58 of 1962

29 Proclamation 21 of 1996.

30 ASISA Standard on living annuities (SLA) Effective - 31 March 2010 at 2, available at: <https://www.asisa.org.za/media/qfrja5mf/asisa_livingannuitystandard_20190820.pdf> (last accessed 11 October 2021). 
date that they exit their retirement funds purchase from financial institutions as investments that will entitle them to draw a monthly income post their retirement. ${ }^{31}$ It is worth noting that some retirement funds also have a living annuity option.

When a retirement fund member purchases an annuity, the capital amount paid either to the insurer or the fund is invested in specific asset classes according to the annuitant's preferences. ${ }^{32}$ The retirement fund member can decide how the underlying assets should be managed. The member can also choose a rate at which he or she can draw from the invested capital amount. When the annuitant dies, the assets remaining in their living annuity pass on to their heirs. ${ }^{33}$ "The nature of living annuities is such that clients bear investment and longevity risk in full. The income over the annuitant's lifetime will ultimately depend on the length of that lifespan, drawdown rates selected and the investment performance of the chosen funds." ${ }^{34}$ Because living annuities do not offer protection against longevity and the possibility of outliving the invested amounts, annuitants should be somewhat conservative when deciding on the amount to draw from their annuity. ${ }^{35}$

Pension funds are structured in such a way that when their members retire, they will only be allowed to take no more than one-third of the total value of their retirement interests as a single payment. They are legislatively mandated to leave at least two-thirds thereto, which will be paid in the form of an annuity (including a living annuity). ${ }^{36}$ As from 1 March 2021, there will also be mandatory annuitization of two-thirds of provident fund benefits on retirement. ${ }^{37}$ These amendments are essentially meant to curb the lump sum payments made by provident funds to their members when they retire. These amendments are only applicable to the retirement fund contributions made as from 1 March 2021. In other words, retirement contributions already

31 See M $v$ M (14/26868) [2016] ZAGPJHC 387 (10 August 2016), para 5, where the court held that "[a] living annuity is defined as an investment product that provides an income upon the annuitant's retirement from a pension fund. The annuitant has little flexibility with what he can do with the living annuity which is rigorously regulated by the Income Tax Act No 58 of 1962 (Income Tax Act). The annuitant can for example choose an income from a range between $2.5 \%$ and $17 \%$ per annum, he can nominate a beneficiary of what remains of the living annuity on his death and in the absence of a nominee it devolves on the annuitant's estate. In the normal course "where the term annuity is involved, the substance of the transaction will involve an investment of a capital sum by an investor to produce a return to the annuitant, calculated by reference to that capital sum to which is applied an agreed or defined percentage interest rate'."

32 T Bester "Comparing five annuity options offered at retirement in South Africa" (MCom thesis, Stellenbosch University 2016) at 41.

33 S Peile "The final analysis: Living annuity, or guaranteed annuity?" (2016) Nov Personal Finance 8.

34 ASISA Standard on living annuities (SLA) Effective - 31 March 2010, above at note 30.

35 Peile "The final analysis", above at note 33 at 8.

36 Sec 1(c)(ii)(dd) of the Income Tax Act.

37 Sec 74 of the Taxation Laws Amendment Act 23 of 2020. 
invested with provident funds before this date, and the investment returns thereto, can still be taken by members as lump sums. Provident fund members who accumulated substantial retirement benefits before this date still have an opportunity to take a substantial amount of money from their provident funds, which they can use to purchase living annuities, to the prejudice of their spouses.

It is generally accepted that a living annuity is a vehicle that is meant for people who have reached retirement or early retirement age. Retirement fund members invest in living annuities through their retirement benefits in order to secure regular income post their retirement. ${ }^{38}$ Once living annuities have been purchased, retirement members will cease to be members of their retirement funds and their membership will be terminated in accordance with the rules of their funds. ${ }^{39}$ This is confirmed in the general Note 18 , Second Schedule to the Income Tax Act, where it is stated that “... retirement funds may terminate their continued liability in respect of a retiring member once an annuity has been purchased for him or her" ${ }^{40}$ The law does not clearly indicate whether in-fund living annuities are the same as out-of-fund living annuities that are provided by insurance companies. There is no doubt that living annuities provided by insurance companies are insurance products that are owned by such insurance companies, wherein annuitants only derive a right to receive a monthly annuity. Can the same be said with in-fund living annuities? Do retirement funds sell insurance products? These are issues that need urgent legislative attention in order to clarify the law in this regard. ${ }^{41}$ It is, nonetheless, generally accepted that in relation to in-fund living annuities, annuitants remain members of their pension funds. ${ }^{42}$

Given the latitude of choice that provident funds provide their members, some members may choose to take their entire retirement benefits in cash. To ensure that these members do not outlive their savings, provident funds (which are defined contribution funds) are now obliged to include in their investment policy statement one or more default investment portfolios for

38 Sec 1 of the Income Tax Act. See also Discovery "retirement income plan", available at: <https://www.discovery.co.za/assets/discoverycoza/investments/retirement-income-plan. pdf> (last accessed 22 May 2020).

39 L de la Harpe "FSLGA changes: Living annuities and divorce" (2015) 3 Insurance and Tax Journal 29.

40 https://www.sars.gov.za/wp-content/uploads/Legal/Notes/LAPD-IntR-GenN-2012-18General-Note-18-Providing-Annuities-Retirement-Employment.pdf (last accessed 20 October 2021).

41 See K Hanekom Manual on Retirement Funds and Other Employee Benefits (2015), para 19.1.10 at 932, in which it is argued that "[i]t needs to be investigated whether an annuitant's rights under an 'in-fund living annuity' and a living annuity individually owned by the annuitant are identical."

42 M Botha 'Living annuities not part of assets for divorce purposes: ST $v$ CT (1224/16) [2018] ZASCA 73", available at: <https://www-mylexisnexis-co-za.ezproxy.uct.ac.za/Index.aspx\#> (last accessed 22 May 2020). 
members who choose not to specify the way in which their benefits should be invested. ${ }^{43}$ The boards of provident funds, where the rules of their funds enable members to elect annuities, are now obliged to establish an annuity strategy. ${ }^{44}$ As part of this default annuity strategy, “... living annuities may be paid directly from the fund or through a fund owned policy or sourced from an external provider ...". ${ }^{45}$

\section{Judicial framework}

It appears that once living annuities have been purchased, either in-fund or out-of-fund, on retirement by retirement fund members through their retirement benefits, the fund used to purchase those living annuities loses its "pension character" and becomes an insurance product to which members merely have a right. Nonetheless, and despite it being defined in the Income Tax Act, the nature of a living annuity as a financial asset, as well as who bears the ultimate control over it, remains unclear in South African law. The question of ownership of the money invested in living annuities has not yet been authoritatively determined in South Africa. It is clear, however, that when purchasing a living annuity, a retirement fund member uses their capital amount to secure guaranteed periodic payments until the invested capital amount has been exhausted. It was confirmed in Commissioner, South African Revenue Service $v$ Higgo that, while entitled to the annuity and not the capital amount, the annuitant will nevertheless be in control of the investment of their capital amount in a living annuity. ${ }^{46}$

Despite the alleged control that the annuitant is said to have over the capital amount and how much to draw in line with legislative guidelines, the South African law on this issue appears to be that living annuities do not form part of former retirement fund members' estates and thus, cannot be taken into consideration when spouses divorce. This is apparent from $M v M .^{47}$ In this case, the parties were married to each other out of community of property subject to the accrual system. During the marriage, the husband acquired two retirement annuities when he ceased to be a member of his retirement fund due to retirement. The court had to determine whether living annuities that were purchased long before the parties' divorce proceedings formed part of the accrual of the husband's estate on divorce. ${ }^{48}$ The court held that because the statutory purpose of a living annuity was to provide an income stream, therefore the living annuity does not form part of the plaintiff's estate for the purposes of accrual. ${ }^{49}$

43 Regulation 37(1) of the Regulations to the PFA.

44 Regulation 39(1)(b) of the Regulations to the PFA.

45 Regulation 39(3)(b) of the Regulations to the PFA.

462007 (2) SA 189 (C) 197.

47 (14/26868) [2016] ZAGPJHC 387 (10 August 2016).

48 Ibid, para 1.

49 Id, paras 29 and 30. 
The SCA confirmed the approach followed by the High Court in $M v M$ when it was faced with the same matter in ST $v$ CT. ${ }^{50}$ In the latter case, the parties were also married to each other out of community of property with the application of the accrual system. During the marriage, the husband also purchased a living annuity using his retirement benefits. The court held that, having regard to the contract that the husband entered into with the insurance company that sold him his living annuity, the capital value used to purchase the living annuity cannot be included as part of his accrual because it did not belong to him, but to the insurance company. ${ }^{51}$ The court further held that the husband's “... only contractual right is to be paid an annuity in an amount selected by him within the permissible range specified by law". 52

The law as set out in $M v M$ and ST $v$ CT seems to be fair at first sight in that it enables retirement fund members to secure their financial future through the proceeds of their retirement benefits. Further, that the legislature has realized the potential for members to misuse their accumulated retirement savings over a short period of time, thereby running the risk of outliving such savings. To prevent this, the legislature made provision for retiring members to be able to invest in living annuities in order to secure periodic payments that would enable them to financially sustain their lives post their retirement. However, it does not seem as though the legislature, in crafting the law, and the courts, in restrictively interpreting the law, carefully considered the matrimonial principles that directly impact on retirement fund members and their retirement benefits at the time when decisions to purchase living annuities are made. It also appears as if the courts, in applying either the pension law principles relating to the protection of retirement benefits or insurance principles relating to who owns living annuities as insurance products, have not adequately considered matrimonial principles.

The SCA also failed to assess the true nature of the capital that was used to purchase living annuities in CM $v$ EM. ${ }^{53}$ In this case, spouses were married out of community of property with the application of the accrual system. The husband, at different stages, purchased three living annuities using his retirement benefits. The SCA confirmed its decision in ST $v$ CT and held that the capital of the husband's living annuities was not susceptible to the wife's accrual claim

\footnotetext{
502018 (5) SA 479 (SCA).

51 Id, para 108.

52 Ibid, the court further held that "[h]is right to receive any particular annuity instalment is subject to a condition of survivorship, ie that he should be alive on the date on which the next annuity instalment becomes payable. If he does not survive to the next date, the fate of the capital will be determined by whether or not he has nominated a beneficiary. The capital may or may not be paid to his estate, depending on whether or not there is such a nomination." On this point, the SCA overturned the High Court's decision in W $v$ H 2017 (1) SA 196 (WCC), para 36, where the court regarded the husband's living annuity as part of the accrual of the husband's estate.

$53(1086 / 2018)[2020]$ ZASCA 48 (5 May 2020).
} 
on divorce. ${ }^{54}$ However, the SCA held that the wife was not without a remedy. In ensuring that the wife is able to come out of the dispute with something, the SCA applied matrimonial principles that are applicable in marriages in community of property. In particular, the SCA relied on Clark $v$ Clark $^{55}$ and De Kock $v$ Jacobson $\mathcal{E}$ another, ${ }^{56}$ which dealt with the sharing of pension interests on divorce by spouses married in community of property. In essence, the dicta of these cases is that a member spouse's interest in his or her retirement benefits which had not yet accrued, and also in the pension right which has accrued, forms part of the joint estate. ${ }^{57}$ The SCA applied this reasoning and declared the value of the husband's future annuity payments in respect of his living annuities to be an asset in his estate for the purposes of calculating the accrual. ${ }^{58}$ This meant that the wife was entitled to share in the husband's future annuity payments. ${ }^{59}$

The main difficulty with this decision is the SCA's failure to properly assess the character of capital that was used to purchase living annuities. In particular, to assess any interest that the non-member spouse might have had at the time this money accrued to the member spouse immediately before living annuities were purchased. Such an assessment could have assisted the SCA in determining whether living annuities were purchased through the financial resources that non-member spouses were, in law, entitled to share. If the non-member spouse at the time the member spouse's retirement benefit accrued had a financial interest in such benefit, the unilateral act of the member of purchasing living annuities may well amount to depriving them of the right to share in that accrued benefit, particularly when the parties are likely to divorce. I am of the view that if the SCA had applied the principles expressed in Clark $v$ Clark and De Kock $v$ Jacobson $\mathcal{E}$ another in relation to the time the living annuities were purchased, it would have been able to adequately assess the non-member spouse's interest in the capital amount used to purchase living annuities. Adequate application of matrimonial principles is necessary to protect non-member spouses' rights in the accrued retirement benefits that member spouses put beyond their reach through living annuities. As it will be shown in the next section, the lack of adequate attention to matrimonial principles has effectively allowed retirement fund members to use living annuities as efficient financial vehicles for the purpose of preventing their spouses from claiming and receiving money to which they are entitled.

54 CM $v$ EM, para 38.

551949 (3) SA 226 (D).

561999 (4) SA 346 (W) 349

57 CM $v$ EM, paras 38 and 39.

58 Ibid.

59 See D Kgole and C Marumoagae "Finding clarity on the division of living annuities during divorce" 2020 (Nov) De Rebus 18. 


\title{
THE IMPORTANT ROLE OF MATRIMONIAL PRINCIPLES
}

It would be trite to say that marriage in community of property is a default marital regime that can only be avoided when parties conclude an antenuptial contract in order to marry either out of "direct" community of property or community of property with the application of the accrual system. ${ }^{60}$ The practical effect of a marriage in community of property is simply that the parties' assets and liabilities incurred before and during the marriage are together pooled into a joint estate that is held by the parties in co-ownership and equal undivided shares. ${ }^{61}$ It is generally accepted in South African law, as correctly argued by Hahlo, that "[c]ommunity of property is a universal economic partnership of the spouses. All their assets and liabilities are merged in a joint estate, in which both spouses, irrespective of the value of their financial contributions, hold equal shares". ${ }^{62}$ In terms of section 14 of the MPA:

\begin{abstract}
"a wife in a marriage in community of property has the same powers with regard to the disposal of the assets of the joint estate, the contracting of debts which lie against the joint estate, and the management of the joint estate as those which a husband in such a marriage had immediately before the commencement of this Act."
\end{abstract}

This provision identifies three important rights in the form of powers that parties to the marriage in community of property have in relation to their joint estate. The parties to the joint estate have the same powers to bind and manage the assets falling within their joint estate. But most importantly, for the purposes of this article, they have the same right to dispose of the assets that constitute their joint estate. ${ }^{63}$ The parties to the joint estate will by operation of law have the same powers over any asset that accrues to their joint estate. This suggests that, once such property has officially fallen within the joint estate, it cannot in law be utilized for the sole benefit of any of the parties to the exclusion of the other. None of the spouses should be denied the right to share benefits that will arise because of the "exploitation" of the assets that accrued to the joint estate, irrespective of who brought it to the joint estate.

It is worth noting that the fact that spouses to the joint estate have the same powers over their joint estate does not mean that they cannot act independently from each other. Section 15(1) of the MPA empowers spouses married

60 Holomisa $v$ Holomisa and Another 2019 (2) BCLR 247 (CC), para 22.

61 D v D (15402/2010) [2013] ZAGPJHC 194 (10 May 2013), para 14. See also Mmampane and Another v Mmampane nee Moshitoa (54061/2014) [2015] ZAGPPHC 420 (29 May 2015), para 1.

62 HR Hahlo The South African Law of Husband and Wife (5th ed, 1985, Juta) 157-58. Hahlo's view has been endorsed by South African courts. See for instance, Schrepfer $v$ Ponelat (17318/2009) [2010] ZAWCHC 193 (26 August 2010), para 7.

63 See generally, Vukeya $v$ Ntshane and Others (518/2019) [2020] ZASCA 167 (11 December 2020), para 32. 
in community of property to perform juristic acts that relate to the joint estates without the consent of their other spouses. However, the legislature has identified several legislative acts that spouses who co-own joint estates cannot perform without the written consent of their other spouses. In particular, section $15(2)(c)$ of the MPA specifically provides that a spouse:

"...shall not without the written consent of the other spouse alienate, cede or pledge any shares, stock, debentures, debenture bonds, insurance policies, mortgage bonds, fixed deposits or any similar assets, or any investment by or on behalf of the other spouse in a financial institution, forming part of the joint estate." ${ }^{n 4}$

There is little doubt that this provision is far from being clear inasmuch as retirement benefits are concerned. Nonetheless, it is submitted that the phrase "or any investment" includes retirement benefits that are invested in other financial vehicles such as living annuities and retirement annuity funds. Thus, there is also little doubt that, when living annuities are purchased through the monetary proceeds of retirement benefits, they constitute investments that former retirement fund members make to ensure that they do not outlive their retirement savings. South African law does not clearly describe the nature of the accrued retirement benefits that are used to purchase living annuities. Neither the legislature nor the courts has adequately considered whether these benefits, at the time they accrue to retirement fund members, also accrue to the joint estate.

It appears as if, as provided for in $M v M$ and ST $v$ CT, there is an incorrect judicial assumption that retirement funds only accrue to retirement fund members, but do not constitute part of their estates, either for the purposes of accrual if the member is a party to a marriage where the accrual system is applicable, or the joint estate if the member is party to a marriage in community of property. ${ }^{65}$ It is submitted that this judicial assumption is not only wrong, but that it also fails to adequately entertain matrimonial principles in general and section 15(2)(c) of the MPA in particular. It cannot be denied that

64 See also Van den Berg $v$ Van den Berg [2004] JOL 12404 (T), para 10, where the court held that "[s]ection 15(2)(c) of the Act provides that a spouse in a marriage in community of property shall not without the written consent of the other spouse alienate, cede or pledge any shares, insurance policies etc forming part of the joint estate." See also Visser $v$ Hull and Others 2010 (1) SA 521 (WCC), para 5, where it is held that "[t]he ambit of section 15 should be interpreted as intended to protect the one spouse against the illicit selling or alienation of property forming part of the joint estate by the other spouse who does that without the knowledge and/or consent of the innocent spouse."

The SCA perpetuated this view in M and Another $v$ Murray and Others 2020 (6) SA 55 (SCA), para 36, where this court, and without considering its decision in Ndaba $v$ Ndaba 20171 SA 342 (SCA), seemed to incorrectly suggest that accrued pension benefits do not constitute the member's estate, in that for these benefits to form part of the member's estate they must have been paid to the member. This issue is beyond the scope of this article; I will deal with it a separate article. 
at the time retirement benefits accrue to members, the retirement funds are obliged to calculate what is due to their members in terms of cash. This process clearly demonstrates that retirement benefits are financial assets that cannot be said not to constitute part of retirement fund members' estates. This is simply because such assets increase the value of retirement fund members' personal estates. If members are married in community of property, it thus follows that these financial assets not only constitute part of their personal estates, but also form part of their joint estate.

It is submitted that the legal position as provided for in $M v M$ and ST $v$ CT is unsound and cannot be sustained. There is no legal justification for not treating accrued retirement benefits that are used to purchase living annuities as assets that constitute retirement fund members' estates. Retirement fund benefits are not, and cannot be treated like, life risk-only insurance policies in which payment on such policies occurs only upon the death of the insured persons/annuitants. While living annuities are insurance products, however, unlike ordinary insurance contracts wherein premiums are paid to cover particular risks, with a living annuity a capital amount is paid upfront to an insurance company to invest and provide periodic payments to the insured/annuitant. Thus, from the start, the insurance company receives money from the insured/annuitant, the value of which can be quantified and paid at any time, should the court so order. The mere fact that accrued retirement benefits have been turned into insurance products through living annuities, and which are then used by member spouses as effective and legal vehicles to hide those benefits, should not be justification for non-member spouses' to be deprived of their share of those benefits. I submit that where member spouses purchased living annuities for the purpose of preventing non-member spouses from sharing thereon, particularly when they were purchased shortly before the parties' divorce, the capital amount received by the insurance company should be considered as the amount that the nonmember spouse ought to benefit from. This amount may be less than the periodic payments already made to the insured/annuitant on the date of divorce, on the assumption that such money was used for the benefit of both parties unless the contrary is proved.

I concede that the South African courts have correctly determined that risk-only insurance policies are not assets in the estates of the policyholders because, unlike retirement benefits, the proceeds of these policies can never be paid to policy holders because they mature only upon their death. ${ }^{66}$ In life insurance contracts, policy holders have to pay premiums and do not have corresponding claims for payment from those policies during their lifetime. ${ }^{67}$ However, with retirement benefits, members who paid contributions over a period of time are themselves able to receive their retirement benefits

66 See Borman en De Vos, NNO en ' $n$ ander $v$ Potgietersrusse Tabakkorporasie BPK en ' $n$ ander 1976 (3) SA 488 (A) 507A.

67 See Pieterse $v$ Shrosbree NO and others, Shrosbree NO $v$ Love and others 2005 (1) SA 309 (SCA), 
when they are dismissed, retrenched, resign or retire during their lifetime. It is thus submitted that, when retirement fund members become entitled to receive retirement benefits at the time when such benefits accrue, such benefits will constitute part of their estate, and if married in community of property, their joint estate. As such, necessary amendments should be made to the pension law legislation to prevent member spouses from hiding these assets in living annuities.

It is further submitted that at the time retirement benefits accrue to the joint estates, they become patrimonial benefits within such joint estates. This automatically provides non-member spouses with equal rights to the accrued retirement benefits in terms of section 14 of the MPA. Once they have acquired the right of ownership over the undivided accrued retirement benefits, they ought to be consulted in terms of section 15(2)(c) of the MPA when a decision to invest such benefits is taken. The SCA, in Naidoo $v$ Discovery Limited and Others, held that "[s]ection 15(2)(c) of the Act creates an exception to the general rule by prohibiting a spouse married in community of property from alienating an asset in the joint estate without the written consent of the other spouse." 68 This demonstrates that once retirement benefits have accrued to the joint estate, the financial proceeds thereof cannot be utilized to purchase a living annuity without the written consent of the other spouse. Based on this, it is further submitted that the other spouse to the joint estate must be part of the decision to invest the proceeds of the retirement benefits in a living annuity.

As co-owners of the accrued retirement benefits which now form part of the joint estate, non-member spouses have a substantial interest in how such retirement benefits, once received (and now as part of the joint estate), ought to be invested, because any reckless or negligent investment made without their involvement might potentially prejudice their interests in the said benefits. It is reasonable to assume that non-member spouses, particularly those in financially weaker positions, most of whom, in practice, are women, will never agree to an investment that deprives them of their entitlement in a manner in which living annuities do. It appears that the proper engagement with matrimonial principles suggests that, to the extent that such investment is made without the written consent of the other spouse for the sole benefit of the one spouse, that transaction will then be unlawful. As will be shown below, this not only amounts to unlawful deprivation of property but is also potentially unconstitutional.

It is correct, as observed by the SCA in Naidoo $v$ Discovery Limited and Others, that “... whilst the intention of the Legislature was to give both spouses equal right of disposal with regard to the joint estate, that does not indicate a

contd

para 12 , where the court stated that "[i]n the ordinary course the proceeds of an insurance policy will go directly to a nominated beneficiary." 
general intention that they should act jointly in all transactions". ${ }^{69}$ However, one should not lose sight of the fact that section 15(2)(c) of the MPA expressly states those transactions that spouses married in community of property cannot perform without the written consent of their other spouses. Spouses are legislatively prohibited from independently making investments through the assets of the joint estate without the written consent of their spouses. It is unfortunate that South African courts, when dealing with disputes regarding living annuities purchased through those retirement benefits that have accrued to their joint estates, do not adequately deal with matrimonial principles, to the detriment of financially weaker spouses.

It is submitted that this enables financially stronger spouses, usually men, to use living annuities as safe legal vehicles by which to deprive financially weaker spouses, usually women, of the financial assets of their marriages to which they are legitimately entitled based on the matrimonial property systems applicable to their marriages. It is recommended that section 15(2)(c) of the MPA must be amended to clarify the law by inserting the phrase "accrued retirement benefits" in that section. This will prevent retirement fund members married in community of property from independently depriving their spouses of accrued retirement benefits through living annuities. The law should further be clarified by defining accrued retirement benefits as retirement savings that constitute part of retirement fund members' estates. This will enjoin courts to consider accrued retirement benefits when dealing with disputes relating to the calculation of the accrual of the estates of retirement fund members who are married subject to the accrual system.

\section{DEPRIVATION OF PROPERTY}

Section 25(1) of the Constitution is generally known as the property clause in South Africa. However, neither the Constitution in general, nor section 25 of the Constitution in particular, defines the word "property". In this article, it is submitted that accrued retirement benefits of retirement fund members married in community of property constitute assets within their joint estates. Section 1(a) and (b) of the Tax Administration Act $^{70}$ defines the word "asset" as including "property of whatever nature, whether movable or immovable, corporeal or incorporeal and a right or interest of whatever nature to or in the property". This entails that before retirement benefits accrue, retirement members merely have an interest in these benefits and a corresponding right to receive them once they have accrued. Retirement members receive accrued retirement benefits in the form of movable property that has been turned into cash. This money is paid into their bank accounts or invested in line with their instructions and the rules their funds. In terms of section 1

69 Ibid.

70 Tax Administration Act 28 of 2011. 
of the Prevention of Organised Crime Act,71 the word "property" "means money or any other movable, immovable, corporeal or incorporeal thing and includes any rights, privileges, claims and securities and any interest therein and all proceeds thereof". ${ }^{72}$ The Pension Funds Adjudicator in Atkinson and Others $v$ Southern Field Staff Defined Contribution Pension Fund determined that "[p]ension benefits as well as additional benefits such as withdrawal benefits under a pension fund are deferred pay and therefore property." 73

It is beyond doubt that retirement benefits constitute property and that when members are married in community of property they accrue to the joint estate. It is now important to assess whether retirement funds members' decision to purchase living annuities using the proceeds of retirement benefits that have accrued to their joint estates amounts to depriving their nonmember spouses of their entitled property. If this does amount to deprivation of property, then whether such deprivation is arbitrary will also need to be assessed. Section 25(1) of the Constitution clearly provides that "[n]o one may be deprived of property except in terms of law of general application, and no law may permit arbitrary deprivation of property". South African courts and academics have over the years attempted to explain what the word "deprivation" means. According to Marais “[t]he term 'deprivation' ... forms part of the state's police power to regulate the use, enjoyment and exploitation of property in the public interest ... usually without compensation." 74

A review of the Constitutional Court cases reveals that in some of the cases this court has adopted a narrow ${ }^{75}$ explanation of the word "deprivation", whereas in others it has described it more broadly. ${ }^{76}$ Various South African academics have engaged the approaches of different judges of the

71 Prevention of Organised Crime Act 121 of 1998.

72 J Veldsman and R Ker "Joint estates: Clarification on the alienation of assets" (2018) Oct De Rebus 30.

73 [2000] 4 BPLR 367 (PFA), para 45.

74 "Narrowing the meaning of 'deprivation' under the property clause? A critical analysis of the implications of the Constitutional Court's Diamond Producers judgment for constitutional property protection" (2018) 34 South African Journal on Human Rights 167 at 175. See also PJ Badenhorst “An arbitrary deprivation of property? The South African constitutional court's decision on s 89(5)(B) of the National Credit Act, 34 of 2005, in Chevron (PTY) LTD $v$ Wilson's Transport” (2016) 22 Canterbury Law Review 103 at 105.

75 See for instance, Mkontwana $v$ Nelson Mandela Metropolitan Municipality 2005 (2) BCLR 150 (CC), para 32, where it was held that "[w]hether there has been a deprivation depends on the extent of the interference with or limitation of use, enjoyment or exploitation. It is not necessary in this case to determine precisely what constitutes deprivation. No more need be said than that at the very least, substantial interference or limitation that goes beyond the normal restrictions on property use or enjoyment found in an open and democratic society would amount to deprivation."

76 See for instance, First National Bank of SA Ltd t/a Wesbank $v$ Minister of Finance (FNB) 2002 (4) SA 768 (CC), para 57 (hereafter FNB case), where it was held that "[i]n a certain sense any interference with the use, enjoyment or exploitation of private property involves 
Constitutional Court regarding the definition of the word "deprivation", thus, it is unnecessary to deal with this aspect in this article. ${ }^{77}$ It suffices to note that the Constitutional Court approach is that deprivation of property will only occur where the interference with property is "substantial". ${ }^{78}$ Regarding non-member spouses, the deprivation will indeed be substantial when living annuities are literally purchased from the assets of the joint estate for the sole benefit of member spouses. These transactions effectively deny non-member spouses the benefit that they derived due to their matrimonial property system to enjoy all the patrimonial benefits of their marriages. They are literally being stripped of their ownership of the assets that constitute part of their joint estate. ${ }^{79}$

Section 25(1) of the Constitution clearly stipulates that deprivation of property per se is not unlawful. Deprivation of property will only be unlawful if it is not sanctioned by law of general application. The law of general deprivation requirement dictates that any deprivation of property in the context of section 25 of the Constitution must be authorized through a source of law that is of general application and not designed to specifically target the person or group of persons who are being deprived of their property. This requirement is often considered in terms of section 36(1) of the Constitution, which will generally be used to assess whether or not the intended deprivation of property amounts to unjustifiable limitation of the non-member spouses' right to property. ${ }^{80}$ In Mlungwana and Others $v S$ and Another, the court reminded us that "[t]he limitation of a right in the Bill of Rights needs to be justified under section $36 \ldots$ [which] requires a weighing-up of the nature and importance of the right(s) that are limited together with the extent of the limitation as against the importance and purpose of the limiting enactment". ${ }^{81}$ It would be trite to say that "[t]he rights protected by the Bill of Rights are subject to the

contd

some deprivation in respect of the person having title or right to or in the property concerned."

77 See generally, AJ van der Walt and RM Shay "Constitutional analysis of intellectual property" (2014) 17 Potchefstroom Electronic Law Journal 53 at 55.

78 South African Diamond Producers Organisation v Minister of Minerals and Energy N.O. and Others 2017 (6) SA 331 (CC), para 48.

79 For a comprehensive discussion on the concept of ownership in the context of property law, see N Sibanda "Amending section 25 of the South African Constitution to allow for expropriation of land without compensation: Some theoretical considerations of the social-obligation of ownership" (2019) 35 South African Journal on Human Rights 129 at 132.

80 In S v Makwanyane (1995) 3 SA 391 (CC), para 104, the Constitutional Court held that "[t]he limitation of constitutional rights for a purpose that is reasonable and necessary in a democratic society involves the weighing up of competing values, and ultimately an assessment based on proportionality." See also Dladla and Another $v$ City of Johannesburg and Others 2018 (2) SA 327 (CC), para 55, where it was held that "[f]or the limitations to be justified under section 36, they must first and foremost be authorised by a 'law of general application'. This is a threshold test which must be met before a justification analysis may begin."

812019 (1) SACR 429 (CC), para 57. 
limitations referred to in section 36, to the extent that such limitation is reasonable and justifiable in an open and democratic society based on human dignity, equality and freedom, taking into account all relevant factors", ${ }^{82}$ and further that there must be a rational connection between the limitation and the object that it seeks to achieve. ${ }^{83}$ It is submitted that, given the fact that the object of purchasing living annuities through accrued retirement benefits before divorce (or at the very least its impact) is to deny non-member spouses the use and enjoyment of accrued retirement benefits, there can never be a rational connection between infringement of the non-member spouses' right to property and the object of allowing member spouses to purchase living annuities with accrued retirement benefits when they are about to divorce.

There is no law of general application that expressly deprives non-member spouses of their member spouses' accrued retirement benefits that are used by member spouses to purchase living annuities. Usually, non-member spouses are deprived of these assets by their member spouses' retirement fund rules that enable member spouses to purchase living annuities while these benefits are still held by these funds. Non-member spouses are further deprived of their entitled property because of the way the law was interpreted in $M v M$ and ST $v$ CT without adequate consideration of matrimonial principles. It is submitted that this amounts to unjustified deprivation of their entitled property and thus cannot be justified under section 36 of the Constitution.

Now that it is clear that the purchase of living annuities through assets that have accrued to the joint estate for the sole benefit of the financially stronger spouse amounts to deprivation, it is necessary to determine whether or not this amounts to arbitrary deprivation. Section 25(1) of the Constitution clearly renders arbitrary deprivation as per se unlawful and unconstitutional. In the FNB case, the Constitutional Court held that "... a deprivation of property is 'arbitrary' as meant by section 25 when the 'law' referred to in section 25(1) does not provide sufficient reason for the particular deprivation in question or is procedurally unfair". ${ }^{84}$ The court further held that in order to establish whether there was sufficient reason to justify the deprivation of property, among other things the relationship between the deprivation in question and the ends sought to be achieved by such deprivation must be evaluated. ${ }^{85}$ There is a need to evaluate the link between the member spouse's decision to use accrued retirement benefits that are part of the joint estate to purchase a living annuity, thereby effectively depriving the non-member spouse of the enjoyment, use and exploitation of such benefits, and the fact that he or she will be the sole beneficiary of such conduct, which is the end that is

82 Sebola $v$ Johnson Tiles (Pty) Ltd and Others [2002] 3 BPLR 3242 (PFA), para 43.

83 Minister of Police and Others $v$ Kunjana 2016 (2) SACR 473 (CC) (27 July 2016), para 24.

84 First National Bank of SA Ltd t/a Wesbank $v$ Minister of Finance (FNB) 2002 (4) SA 768 (CC), para 100.

85 Ibid, para 100(a). 
sought to be achieved. The court further held that there is a need to consider "... the relationship between the purpose for the deprivation and the person whose property is affected". ${ }^{86}$ It is clear that the purpose of purchasing a living annuity when there is a joint estate before the divorce is to protect accrued retirement benefits from being shared in accordance with the matrimonial dictates of the marriage. This is to prevent the non-member spouse from receiving any part of such benefits.

The Constitutional Court further held that the "... relationship between the purpose of the deprivation and the nature of the property as well as the extent of the deprivation in respect of such property" 87 must be considered. The property that the non-member spouse is being deprived of is a patrimonial asset of the marriage which the member spouse has "lawfully" removed from the joint estate in order to become the only spouse who will enjoy, use and exploit it. This effectively prejudices the non-member spouse, particularly when he or she is a financial weaker spouse who directly or indirectly assisted the member spouse to accumulate that financial asset during the course of the marriage. The court also held that "[w]hether there is sufficient reason to warrant the deprivation is a matter to be decided on all the relevant facts of each particular case, always bearing in mind that the enquiry is concerned with 'arbitrary' in relation to the deprivation of property under section 25." 88

The conduct of the member spouse in depriving the non-member spouse of accrued retirement benefits is usually permitted by the rules of the fund, which apply to members of the fund and not to the non-member spouse, as well as the way in which the court has dealt with this issue. In fact, the law (rules established in terms of the empowering Act) that is applied to deprive the non-member spouse of accrued retirement benefits does not even apply to the non-member spouse. This is the law that is designed not only to regulate the member's relationship with his or her fund when his or her monthly contributions are invested by the fund on his behalf, but also to determine the circumstances under which invested money will accrue to him or her as well as how it can be invested further in living annuities.

In the FNB case, the court merely provided guidance on how sufficient reason can be established when determining arbitrariness of the deprivation of property and did not definitively prescribe how it ought to be established. Thus, future courts when dealing with claims relating to deprivation of property “... have the freedom to strike an appropriate balance between the conflicting individual and social rights that are implicated by the laws that are designed to or have the effect of depriving persons of property, without being constrained by an artificial list of pre-determined factors or

86 Id, para $100(\mathrm{c})$.

87 Id, para $100(\mathrm{~d})$.

88 Id, para $100(\mathrm{~h})$ 
considerations". ${ }^{89}$ As such, it is submitted that the law as expressed in $M v M$ and ST $v$ CT amounts to arbitrary deprivation of property and thus unconstitutional.

It is recommended that, when any court in future is faced with a claim of deprivation of accrued retirement benefits, it should carefully consider the nuances presented by matrimonial principles. In its analysis, it should strike a proper balance between the law as it is currently applied and the effect of deprivation on the non-member spouse, taking into account his or her entitlement in accordance with the matrimonial property regime applicable to his or her marriage. This analysis will illustrate to the court that the approach followed in $M v M$ and ST $v$ CT leads to effective arbitrary deprivation of property and thus unconstitutional. It has been correctly argued that "... depending on all the factors, it may sometimes be enough to show that there is a rational link between the purpose of the deprivation and the impact thereof". ${ }^{90}$ However, it is submitted that there is no rational link between the law as expressed in M $v$ M and ST $v$ CT and allowing member spouses to use accrued retirement benefits to purchase living annuities without consulting their nonmember spouses, as dictated by section 15(2)(c) of the MPA.

Once retirement benefits have accrued, arbitrary deprivation of property will take place immediately when the fund, on behalf of its member, purchases a living annuity for its member without regard to matrimonial principles that bind the member. The fund will be acting in terms of its rules and in accordance with either the direction or agreement of its member without consultation with the non-member spouse to the prejudice of the non-member spouse, particularly when parties are about to divorce. ${ }^{91}$ It is hoped that judges presiding over future cases that deal with member spouses who have purchased living annuities on the eve of their divorce by using their accrued retirement benefits will protect non-member spouses by adequately taking into account matrimonial principles. The legislature should come to the aid

89 M Kruger "Arbitrary deprivation of property: An argument for the payment of compensation by the state in certain cases of unlawful occupation" (2014) 131 South African Law Journal 328 at 338.

90 R Brits “Arbitrary deprivations of an unregistered credit provider's right to claim restitution of performance rendered - Opperman $v$ Boonzaaier (24887/2010) 2012 ZAWCHC 27 (17 April 2012) and National Regulator v Opperman 20132 SA 1 (CC)” (2013) 16 Potchefstroom Electronic Law Journal 421 at 447.

91 It is generally accepted that this enquiry amounts to substantive fairness of the deprivation. Some authors have noted as well that there is a need for deprivation of property also to be procedurally fair. This debate is beyond the scope of this article. See generally, AJ van der Walt "Procedurally arbitrary deprivation of property" (2012) 1 Stellenbosch Law Review 88-94 and Kruger "Arbitrary deprivation of property", above at note 89 at 543, who argues that "[i]f the law that authorises the state to conduct forced judicial sales of debtors' properties 'does not provide sufficient reason for the particular deprivation in question', the deprivation will be arbitrary. It will also be arbitrary if the deprivation is 'procedurally unfair'." 
of all non-member spouses, irrespective of whether they are divorcing, by making it clear that accrued retirement benefits form part of retirement fund members' estates. Further, that if such members are married in community of property, before they can purchase living annuities with such benefits, they should consult their spouses, and failure to do so will amount to arbitrary deprivation of property.

Finally, it is worth noting that the Pension Funds Adjudicator has also determined that "[the] right to a pension benefit, being a right to property, deserves to be protected by the Constitution." 92 The first Pension Fund Adjudicator, John Murphy (now a high court judge), when analysing the basis of this right in relation to retirement fund members, held that this protection is necessary "[b]ecause that right is intimately related to one's own efforts and achievements, as opposed to being an ex gratia payment from the employer, it is equivalent to a right in property." 93 It cannot be doubted that this right also extends to non-member spouses married in community of property. Most importantly, Murphy, in Atkinson and Others $v$ Southern Field Staff Defined Contribution Pension Fund, ${ }^{94}$ determined that:

"[t]here is nothing in this clause, nor in the rest of the property section, that precludes its horizontal application, that is which would limit its applicability to protection against organs of state only. The safeguard is against arbitrary deprivation and the State is not the only potential culprit. Many large private institutions are repositories of social and economic power of a quasi-public nature and hence there should be no reason why the guarantee in section 25 cannot be applied to protect the individual from any arbitrary conduct by such bodies, including pension funds performing a public function."

This quote underscores the point that there is no legislation in South Africa that allows for the deprivation of retirement fund members' benefits. Neither is there a statutory provision that empowers member spouses to deprive their spouses of the accrued retirement benefits. Murphy was simply illustrating that in the context of retirement benefits, the deprivation of property will be occasioned by retirement fund rules. Thus, the courts must be vigilant and guard against retirement fund rules that enable retirement fund boards of management to deprive either their members or their members' spouses of their entitled and accrued retirement benefits.

92 Sebola $v$ Johnson Tiles (Pty) Ltd and Others [2002] 3 BPLR 3242 (PFA), para 41.

93 Ibid, para 42, Murphy further determined that "[p]ension rights have been recognised as falling within the concept of property in international jurisdictions like Germany and the United States, and constitutional recognition has been extended to access to state benefits like pensions, jobs, housing, contracts, licences, and so on." See also Manzini v Metro Group Retirement Fund and Another (1) [2001] 12 BPLR 2808 (PFA), para 39. [2000] 4 BPLR 367 (PFA), para 35. 


\section{CONCLUSION}

This article represents a call for law reform that would clarify the law regarding the rights of spouses when their other spouses who are members of retirement funds exit their retirement funds and purchase living annuities. In particular, this article argued that allowing retirement fund members who are married in community of property to purchase living annuities using proceeds of retirement benefits that accrued to their joint estate amounts to unfair discrimination and arbitrary deprivation of their property, and is thus unconstitutional. In short, the law as expressed in $M v M$ and ST $v$ CT, and to a large extent the rules of various retirement funds, enable member spouses who are married in community of property to deprive their spouses of their entitled financial assets. The way these cases have been decided illustrates that non-member spouses lack the rights to claims to property to which they, in accordance with matrimonial principles, are entitled. These cases confirm that non-member spouses on divorce do not have a claim to the capital amount of their member spouses' living annuities because living annuities are simply not regarded as constituting part of the annuitants' estates.

The main, and obvious, difficulty with this state of affairs is that, in terms of pension law, accrued retirement savings are generally regarded as assets in the members' estate for the purposes of divorce in terms of section 7(7) of the Divorce Act. ${ }^{95}$ However, once retirement fund members instruct their funds to purchase living annuities with third-party insurance companies, or their funds arrange in-fund annuity arrangements for their members in terms of the rules, these accrued retirement benefits are not regarded as assets in the retirement fund members' estates. It is recommended that the legislature urgently attend to the clarification of the law in order to prevent further prejudice being experienced by non-member spouses when member spouses unilaterally and independently decide to purchase living annuities using retirement benefits that have accrued to the joint estate.

\section{CONFLICTS OF INTEREST}

None

95 See generally, Marumoagae "The law regarding pension interest in South Africa has been settled!", above at note 1 at 4 . 